\title{
WSPÓŁCZESNE KONCEPCJE ODDZIAŁYWAŃ RESOCJALIZACYJNYCH WOBEC OSÓB Z ZAAWANSOWANYMI PRZEJAWAMI ZABURZEŃ W ZACHOWANIU I NIEDOSTOSOWANIA SPOŁECZNEGO
}

\section{Contemporary Concepts of Social Rehabilitation Interactions with People with Advanced Manifestations of Behavioral Disorders and Social Maladjustment}

S u m m a r y: The searching for effective ways of social rehabilitation interactions is based on diverse theoretical trends, which, however, cannot be equated with criminological theories. Models of social rehabilitation interactions refer to many theoretical currents differing methodologically and praxeologically. Behavioral, psychodynamic, cognitive-behavioral, interdisciplinary or interactive concepts are listed among the most important trends. Also noteworthy are the models of corrective actions referring to the evidence based practice movement, examples of which may be the R-N-R and Good Life Model models. The purpose of this study is to characterize selected basic models of corrective interactions currently used in the process of social rehabilitation of people with behavioral disorders, socially maladjusted and perpetrators of crimes. Due to the theoretical nature of the study, a method of searching secondary sources was used.

Keywords: social maladjustment, behavioral disorders, behavioral direction, cognitive model, multidimensional direction, good life model

1 Dr hab. Małgorzata H. Kowalczyk, prof. UMK, Katedra Rewalidacji, Resocjalizacji i Opieki Długoterminowej, Instytut Nauk Pedagogicznych, Wydział Filozofii i Nauk Społecznych, Uniwersytet Mikołaja Kopernika w Toruniu, ul. Lwowska 1, 87-100 Toruń; e-mail: mh.kowalczyk@op.pl. 


\section{Wprowadzenie}

Projektowanie i podejmowanie innowacyjnych rozwiązań resocjalizacyjnych odnosi się do dominujących $\mathrm{w}$ określonym czasie paradygmatów i wynikających z nich kierunków badań skoncentrowanych na rozwiązywaniu problemów ograniczających zakres zachowań dewiacyjnych, niedostosowanych czy przestępczych. Wiodące nurty, wyznaczone rozwojem psychologii i socjologii, wyjaśniały przejawy niedostosowania społecznego czy zaawansowanej jego postaci, czyli przestępczości, koncentrując się na wskazaniu roli osobowości czy akcentowaniu wpływów środowiska. Inspiracji teoretycznych, ukierunkowujących badania naukowe pozwalające na modyfikowanie praktyk resocjalizacyjnych czy projektowanie innowacyjnych rozwiązań w tym zakresie, dostarczyły teorie psychologiczne: behawioryzm, psychoanaliza czy teorie uczenia się. Nurt behawioralny, choć przyczynił się do zredukowania znaczenia woluntaryzmu w kontekście procesów decyzyjnych jednostki oraz promował schematyczność czy rytualizację oddziaływań resocjalizacyjnych, stał się na długi czas zasadniczym nurtem oddziaływań korekcyjnych, skoncentrowanym głównie na modyfikacji zewnętrznych przejawów zachowań. Także w nurcie psychoanalizy (czy szerszym psychodynamicznym) nie można jednoznacznie wskazać wpływu na rozwój oddziaływań resocjalizacyjnych poprzez wskazanie skutecznych strategii, metod czy technik pracy z osobami niedostosowanymi społecznie ${ }^{2}$. Jednak odwołanie się do kierunku psychodynamicznego zmieniło sposób myślenia o resocjalizacji i pozwoliło na uwzględnienie w naukowych teoriach resocjalizacji całości struktury osobowości i jej najważniejszych elementów, czyli sieci wartości i sieci operacyjnej skoncentrowanej wokół struktury Ja. Innowacyjne rozwiązania proponowane są także na gruncie psychologii kognitywnej, zwłaszcza w zakresie objaśniającym genezę, istotę i rodzaje różnych przejawów niedostosowania społecznego. Nie można zapominać także o wskazaniach wynikających z koncepcji interakcyjnych, według których człowiek jest istotą społeczną i wszystkie jego zachowania i reakcje należy rozpatrywać w kategoriach pełnionych przez niego funkcji społecznych ${ }^{3}$. Brak jednoznacznie skutecznego kierunku oddziaływań resocjalizacyjnych skłania do poszukiwania dalszych rozwiązań przy wykorzystaniu wiedzy, doświadczeń i badań prowadzonych w dyscyplinach powiązanych $\mathrm{z}$ resocjalizacją. Kierując się tym zamysłem, w niniejszym opracowaniu przedstawione zostaną wybrane koncepcje resocjalizacji, które stały się podstawą opracowania i wdrażania oddziaływań korekcyjnych wobec osób wykazujących znaczące trudności adaptacyjne na skutek zaawansowanych

2 Kazimierz Pospiszyl, Resocjalizacja (Warszawa: Wydawnictwo Akademickie „Żak”, 1998), 29.

3 Marek Konopczyński, „Współczesne nurty w resocjalizacji”. W: Resocjalizacja, red. Bronisław Urban, Jan Maria Stanik (Warszawa: Wydawnictwo Naukowe PWN, 2007), 206. 
przejawów zaburzeń w zachowaniu i niedostosowania. Opracowanie ma charakter teoretyczny, zatem wykorzystaną metodą jest przeszukiwanie źródeł wtórnych ${ }^{4}$.

\section{Zaburzenia w zachowaniu i niedostosowanie społeczne}

Funkcjonujące w pedagogice resocjalizacyjnej pojęcia zaburzeń w zachowaniu i społecznego niedostosowania zostały obszernie zinterpretowane przez m.in. Bronisława Urbana $(2000,2007)$, także w kontekście ich wzajemnych zależności. Chociaż zaburzenia w zachowaniu (w tym również zaburzenia emocjonalne traktowane jako dominujące) oraz niedostosowanie społeczne stanowią przedmiot zainteresowań w kontekście interwencji resocjalizacyjnych, to jednak nie należy ich traktować zamiennie. Zaburzenia emocjonalne, zaburzenia w zachowaniu czy niedostosowanie społeczne mogą zawierać wspólne elementy konstytutywne, jednak mimo to nie należy utożsamiać ich zakresu treściowego, gdyż pojęcia te wymagają rozróżnienia ${ }^{5}$. Zdaniem Urbana zaburzenia emocjonalne niekoniecznie muszą przejawiać się w zachowaniu i niedostosowaniu społecznym, ale niedostosowanie społeczne zwykle zaczyna się od różnych postaci zaburzeń emocjonalnych. Zatem zaburzenie emocjonalne zazwyczaj prowadzi do zaburzeń w zachowaniu i niedostosowania społecznego ${ }^{6}$. Może stanowić więc przyczynę niedostosowania lub jego wstępny etap, będąc psychologiczną komponentą niedostosowania, które jest zjawiskiem bardziej złożonym, obejmującym zarówno czynniki psychologiczne, jak i socjologiczne ${ }^{7}$. W kontekście tym warto także zwrócić uwagę na zachowania asocjalne, zawierające się w obszarze definiowanym przez pojęcie społecznego niedostosowania. Charakteryzują się one społeczną szkodliwością celów, na których realizację bywają ukierunkowane, oraz wadami w ich strukturze, przy czym oba te komponenty występują zwykle łącznie. Zatem asocjalność stanowić będzie pewien utrwalony styl codziennego funkcjonowania jednostki, charakteryzujący się wskazanymi właściwościami decydującymi o szkodliwości funkcjonowania społecznego w szerszym zakre$s i e^{8}$. W rozważaniach dotyczących zaburzeń $\mathrm{w}$ zachowaniu nie można pominąć ostatniego etapu rozwoju zaburzeń, czyli ścieżki zachowań przestępczych.

4 Krzysztof Rubacha, Metodologia badań nad edukacją (Warszawa: Wydawnictwo Akademickie i Profesjonalne 2008).

5 Jan Maria Stanik, „Diagnozowanie niedostosowania społecznego i asocjalności”. W: Resocjalizacja, 173.

6 Bronisław Urban, „Zaburzenia w zachowaniu i niedostosowanie społeczne w świetle współczesnych wyników badań". W: Resocjalizacja, 141.

7 Tenże, Zaburzenia w zachowaniu i przestępczość młodzieży (Kraków: Wydawnictwo Uniwersytetu Jagiellońskiego, 2000), 18.

8 Stanik, „Diagnozowanie..., 177-178. 
Występujące pomiędzy zaburzeniami w zachowaniu a przestępczością relacje uzasadniają przyjmowanie procesualnego spojrzenia na zachowania przestępcze. Takie ewolucyjne spojrzenie na problematykę przestępczości, której początkiem mogą być zaburzenia w zachowaniu, niedostosowanie społeczne niepodlegające żadnym restrykcjom prawnym, stanowi przedmiot zainteresowania zarówno w kontekście ustalania etiologii zjawiska, jak i z perspektywy resocjalizacji czy readaptacji. Przestępczość traktowana może być jako swoista kariera, która przebiega na kształt sinusoidy i w której aktywność przestępcza może przeplatać się z okresem braku takiej aktywności. Przestępczość może też być postrzegana jako styl życia. W obu przypadkach charakteryzują ją pewne parametry, takie jak powierzchowność, zasięg, specjalizacja, eskalacja, doniosłość w skutkach, intensywność, czas trwania czy zróżnicowanie ${ }^{9}$. Zmiana przebiegu kariery, jak i zmiana stylu życia wymaga między innymi odpowiedniej siły motywacji i gotowości do zmian. Czynnikami różnicującymi zakończenie kariery przestępczej mogą być między innymi czas trwania aktywności przestępczej czy moment rozpoczęcia kariery przestępczej. Nie można pomijać także faktu heterogeniczności zachowań przestępczych, która wiąże się ze zmiennością zachowań przestępczych w różnych okresach życia i aktywności kryminalnej sprawcy ${ }^{10}$. W niektórych przypadkach wspomniana heterogeniczność zachowań przestępczych może być fałszywym wskaźnikiem procesu odchodzenia od przestępczości, ponieważ jedna zanikająca forma aktywności przestępczej może zostać zastąpiona inną formą zachowań dewiacyjnych. Powyższe rozważania pozwalają na stwierdzenie, że zastosowanie w procesie resocjalizacji zróżnicowanych form interwencji zmierzających do zakończenia kariery przestępczej nie zawsze w sposób jednoznaczny oznacza pełną readaptację społeczną byłego przestępcy. Zaniechanie popełniania dalszych przestępstw może wciąż oznaczać trudności w akceptowaniu i przestrzeganiu prospołecznych zasad.

W dalszej części opracowania omówione zostaną współczesne koncepcje proponujące zróżnicowane podejście do kwestii interwencji resocjalizacyjnych wobec osób zdradzających zaawansowane objawy zaburzeń w zachowaniu i niedostosowania, w szczególności wkraczających w obszar przestępczości.

9 Urban, Zaburzenia..., 125.

10 Por. Maciej Muskała, Odstąpienie od przestępczości w teorii i praktyce resocjalizacyjnej (Poznań: Wydawnictwo Naukowe UAM, 2016); Urban, Zaburzenia..., 127. 


\section{Współczesne kierunki (koncepcje) interwencji resocjalizacyjnych}

\subsection{Kierunek oddziaływań behawioralnych}

Podstawą teoretyczną modelu behawioralnego są teorie uczenia się, które zakładają, że zachowania przestępcze są normalną reakcją na nieprawidłowe uwarunkowania, dlatego też resocjalizacja powinna polegać na przewarunkowaniu, czyli stworzeniu społecznego systemu nagradzania (tj. wzmacniania) takich cech, które są pozytywne ze społecznego punktu widzenia. Teorie behawioralne uznają, że człowiek w toku swojego rozwoju społecznego i osobowego uczy się różnych zachowań i reakcji. Uczenie się podlega procesowi wzmocnień, co oznacza, że prawdopodobieństwo wystąpienia i utrwalenia się danych zachowań jest tym większe, im częściej i mocniej są one w sensie psychologicznym utrwalane ${ }^{11}$. Jednym z obszarów, w których terapia behawioralna znalazła zastosowanie, jest resocjalizacja przestępców oraz osób przejawiających różnego rodzaju zaburzenia emocjonalne i antyspołeczne ${ }^{12}$.

Osobowość jest zatem traktowana jako suma dających się zaobserwować rodzajów zachowania, które są całkowicie kontrolowane przez otoczenie. Złe zachowanie jest w związku z tym „zdrową" reakcją na negatywne wpływy otoczenia, a nie symptomem trwałych zaburzeń. Przyjmuje się zatem, że negatywne zachowania i reakcje ujmowane są jako „produkt” procesu socjalizacji, zatem mogą podlegać zmianom. Resocjalizacja odwołująca się do kierunku behawioralnego polega na:

- wyrównaniu braków w zachowaniu - przyjmując, że zaburzenia w zachowaniu często wynikają z licznych niedostatków w różnych sferach funkcjonowania ludzkiego, jednostka taka nie otrzymuje w kontekstach społecznych oczekiwanych wzmocnień pozytywnych, które rozwijają i utrwalają wartościowe ze społecznego punktu widzenia cechy zachowania. Doświadczanie bodźców negatywnych prowadzi zarówno do agresji, jak i do wzmacniania reakcji społecznie nieadekwatnych. Zatem działania resocjalizacyjne powinny koncentrować się na wyrównaniu wspomnianych braków ${ }^{13}$;

- eliminowaniu negatywnych cech zachowania, ponieważ osoby wykazujące zaburzenia w zachowaniu, jak i zachowania antyspołeczne przyswoiły sobie szereg niewłaściwych form zachowania utrudniających im

11 Marek Konopczyński, Metody twórczej resocjalizacji (Warszawa: Wydawnictwo Naukowe PWN, 2006), 31.

12 Pospiszyl, Resocjalizacja, 43.

13 Tamże, 44. 
funkcjonowanie $\mathrm{w}$ społeczeństwie. Zatem zadaniem resocjalizacji behawioralnej jest wyeliminowanie negatywnych przejawów zachowań oraz dostarczenie silnych pozytywnych wzmocnien' ${ }^{14}$;

- wzmocnieniu kontroli własnego zachowania, polegającej na wypracowaniu u osób ujawniających zaburzenia w zachowaniu i zachowania antyspołeczne wystarczająco silnych umiejętności powstrzymania szeregu reakcji i zapanowania nad natychmiastowym uzewnętrznianiem swych emocji, które niejednokrotnie mogą prowadzić do zachowań przestępczych ${ }^{15}$.

Stosowane w resocjalizacji behawioralnej metody są oparte na paradygmatach procesu uczenia się odnoszących się do związków między zachowaniem człowieka a szczególnymi warunkami otoczenia ${ }^{16}$. Przykładem zastosowania terapii behawioralnej w resocjalizacji jest model MBT, stosowany wobec sprawców przestępstw o podłożu seksualnym. Model MBT traktować można jako standardowy schemat terapii stosowany również w Polsce. Leczenie jest czasochłonne, ustrukturyzowane i zawierające ujednolicone formy interwencji. Poszczególne pakiety interwencji są zasadniczo spójne. W modelu MBT wszyscy uczestniczący w terapii poddani są tym samym procedurom. Grupy terapeutyczne tworzą osoby, u których zdiagnozowano podobne problemy lub klastry zaburzeń ${ }^{17}$. Ponieważ wobec wszystkich osób stosuje się podobne schematy oddziaływań powiązane z ich głównym problemem (np. skłonności pedofilne), nie ma potrzeby sporządzania dokładnej diagnozy klinicznej określającej genezę tych problemów ${ }^{18}$.

\subsection{Oddziaływania oparte na modelu psychologii kognitywnej}

Wszelkie ograniczenia w zakresie praktyki resocjalizacyjnej, jakie wynikały z zastosowania założeń behawioralnych, skierowały zainteresowania badawcze na obszar psychologii kognitywnej. W konsekwencji zaczęły dokonywać się przełomowe zmiany w zakresie myśli resocjalizacyjnej, zbliżające się do kierunku wielowymiarowego (eklektycznego). Innowacyjne rozwiązania w zakresie interwencji resocjalizacyjnej wyprowadzane są z psychologii kognitywnej, a zwłaszcza tych jej twierdzeń, które nawiązują do różnych koncepcji osobowości oraz objaśniają istotę oraz rodzaje zachowań agresywnych ${ }^{19}$. Znaczący wpływ na rozważania w obszarze resocjalizacji ma poznawcza teoria osobowości, która wywodzi

14 Tamże.

15 Tamże, 45.

16 Tamże.

17 Tony Ward, Pamela Nathan, Christopher R. Drake, Joseph K.P. Lee, Michele Pathé, „The Role of Formulation-based Treatment for Sexual Offenders”, Behaviour Change 4 (2000), 255.

18 Tamże.

19 Bronisław Urban, „Współczesne teorie w naukach społecznych wobec przestępczości i resocjalizacji”. W: Działalność resocjalizacyjna i profilaktyczna, w środowisku otwartym, instytucjach wychowawczych, poprawczych oraz karnych, red. Teresa Sołtysiak, Agnieszka Latoś (Bydgoszcz: Wydawnictwo UKW, 2010), 12. 
się z psychologii kognitywnej. Jej istotą jest wskazanie, że uwarunkowania reakcji ludzkich i zachowań społecznych mają związek z procesem przyjmowania i przetwarzania informacji przez struktury poznawcze i twórcze (percepcja, motywacja, emocje, pamięć, myślenie, wyobraźnia) ${ }^{20}$. Zasadniczym założeniem poznawczej teorii osobowości, sformułowanym przez George’a Kelly’ego, prekursora kierunku, jest uznanie, że informacje stanowią pierwotny element struktury Ja, tworząc złożone konstrukty osobowościowe funkcjonujące w postaci wiedzy tworzącej sieci operacyjne i sieci wartości. Wiedza zorganizowana w postaci sieci operacyjnej pozwala jednostce na prezentacje określonych postaw wobec otoczenia oraz umożliwia podejmowanie kontaktów interpersonalnych i pełnienie funkcji. Natomiast wiedza zorganizowana wokół sieci wartości ma charakter wartościująco-normatywny i wypełnia treściami aksjologicznymi postawy, relacje i pełnione funkcje ${ }^{21}$. W Polsce teorią nawiązującą do psychologii kognitywnej i będącą inspiracją dla tworzenia kierunków oddziaływań resocjalizacyjnych jest regulacyjna teoria osobowości Janusza Reykowskiego. Osią tej teorii jest system regulacji kształtujący się $\mathrm{w}$ toku socjalizacji na podstawie przyswajanych i przetwarzanych informacji ${ }^{22}$. W systemie regulacji centralne miejsce zajmuje struktura Ja, a oprócz niej system tworzą - jak powiedziano - sieć wartości oraz sieć operacyjna. Wszystkie te elementy systemu regulacji kształtują się pod wpływem informacji, jakie w procesie socjalizacji docierają do jednostki ${ }^{23}$. Sieć wartości, zbudowana z elementów społecznych wymogów, selekcjonuje napływające informacje w obszarze subiektywnej skali „dobre - złe”, „ważne - nieważne”, podporządkowuje sobie mechanizmy popędowo-emocjonalne i decyduje o treści, kierunku i moralnej jakości zachowania jednostki. Natomiast sieć operacyjna ukierunkowana jest na rozumienie zależności i przemian zachodzących w świecie oraz przewidywanie zdarzeń. W obu przypadkach występuje dążenie do redukcji niepewności dotyczącej tego, co ważne, oraz prawdziwości lub fałszywości informacji o rzeczywistości. Sprzeczności, jakie stąd wynikają, wywołują lęk i motywują do działania. Rozwój struktury Ja prowadzi do ukształtowania się tożsamości jednostki, poczucia odrębności od innych, spójności i samoświadomości. Ważnym elementem struktury osobowości jest poczucie kontroli pozwalające na odróżnienie informacji o skutkach własnych poczynań od skutków powodowanych przez działania i aktywność innych, nabieranie przekonania o możliwościach wywierania wpływu przez jednostkę na przebieg zdarzeń, ostatecznie zapewniające poczucie bezpieczeństwa wynikające z przekonania o przewidywalności otaczającej rzeczywistości czy poczucia mocy - wynikającej z kolei z przekonania o własnych możliwościach wpływu na otoczenie ${ }^{24}$. Każda jednostka

\footnotetext{
20 Konopczyński, „Współczesne nurty..., 208.

21 Tamże.

22 Urban, „Współczesne teorie..., 13.

23 Tamże.

24 Tamże, 13-14.
} 
przejawia także poczucie własnej wartości, co bezpośrednio wyraża się w jakości zachowania. Poczucie własnej wartości może być zaniżone lub zawyżone i stanowi jeden z elementów dewiacyjnych cech osobowości. Kształtowanie się osobowości antyspołecznej, która powodować może przejawy niedostosowania społecznego, jest rezultatem odbioru przez jednostkę bodźców niezgodnych ze społecznie akceptowanym systemem wartości ${ }^{25}$.

Zrozumienie struktur osobowości, mechanizmów tworzenia się zaburzonych, antysocjalnych (dewiacyjnych) cech osobowości pozwala na wykorzystanie tej wiedzy do projektowania oddziaływań resocjalizacyjnych. Specyfika tych metod, nawiązujących do psychologii kognitywnej, sprowadza się do „operowania wiedzą, argumentami i informacjami odczytywanymi przez resocjalizowaną jednostkę z zachowań i wzorów prezentowanych przez autorytety. Dzięki czemu cały proces resocjalizacji nabiera świadomego i pozytywnego charakteru i może być traktowany jako działalność optymistyczna"26.

Jednym z przejawów zaburzeń zachowania i niedostosowania jest agresja. W ujęciu kognitywnym etiologia zachowań agresywnych nabiera odmiennego znaczenia, mimo że nie odrzuca czynników wspólnych dla wszystkich zachowań. Różnica między genezą zachowań aprobowanych a agresją polega na uwzględnieniu w przypadku agresji czynników dodatkowych, zawierających się w typie układu nerwowego i temperamencie oraz w czynnikach środowiskowych i zdarzeniach zaistniałych $\mathrm{w}$ przebiegu procesu socjalizacji ${ }^{27}$. Celem zachowań agresywnych jest kontrola zachowań innych oraz ochrona własnej tożsamości, czyli realizacja potrzeb i dążeń. Jednakże samo posłuszeństwo, podporządkowanie ofiary nie stanowi celu samego w sobie. Jest to sposób, droga do osiągnięcia innych pożądanych dóbr czy usług, przy czym nie bez znaczenia jest bilans zysków i strat oraz prawdopodobieństwo osiągnięcia celu, wskazujące, że agresor działa pod wpływem racjonalnego procesu decyzyjnego. Zarówno zachowania agresywne, jak i wrogie zniekształcenia poznawcze rozwijają się u jednostek, które w środowisku społecznym spotykają się wyłącznie lub w dużym stopniu $\mathrm{z}$ informacjami wskazującymi, że zachowania agresywne są najlepszym sposobem realizacji potrzeb, osiągania celu, a więc realizacji Ja. Tradycyjnie jednostkom agresywnym przypisuje się niższy poziom samooceny, jednak jak zauważa Urban, badania nie potwierdzają tego przekonania, wskazując, że do agresji bardziej skłonne są osoby o wysokiej samoocenie, zwłaszcza w sytuacjach postrzeganych przez nie jako zagrażające. Skłonności do zachowań agresywnych znamienne są dla osób prezentujących samoocenę niestabilną i zawyżoną ${ }^{28}$.

\footnotetext{
25 Tamże, 13.

26 Tamże.

27 Tamże, 14.

28 Tamże, 16.
} 
Działania resocjalizacyjne należy zatem kierować na zwiększanie poczucia własnej wartości, co przejawia się w sposobie organizowania samowiedzy, spostrzegania przyczyn własnych zachowań, sukcesów i porażek oraz w wyborze mechanizmów obronnych i regulowania zachowań ${ }^{29}$. Nie mniej istotnym wskazaniem resocjalizacyjnym jest diagnozowanie potrzeb i dążeń jednostek agresywnych. Ważnym wskazaniem resocjalizacyjnym wynikającym z podejścia kognitywnego jest odniesienie się do poczucia kontroli jako ważnego elementu struktury osobowości i jej regulacyjnej roli w odniesieniu do zachowania człowieka. W ujęciu kognitywnym podkreśla się znaczenie metod treningowych w zakresie obserwacji własnych procesów psychicznych i umiejętności ich definiowania, obserwacji wzmagającego się wzburzenia i wściekłości w sytuacjach domniemanego lub rzeczywistego zagrożenia, nabywania umiejętności redukowania napięcia, wypracowania poznawczych i emocjonalnych składników empatii oraz kompetencji tworzenia i podtrzymywania relacji z otoczeniem ${ }^{30}$.

Wspomniane wskazania znalazły swoje praktyczne odzwierciedlenie w wielu metodach treningowych, także tych dotyczących osób agresywnych. Przykładem jest chociażby stosowany w polskich placówkach resocjalizacyjnych i penitencjarnych trening kontroli złości opracowany na podstawie programu ART ${ }^{31}$. Założenia terapii kognitywnej w powiązaniu z terapią behawioralną znajdują także zastosowanie w resocjalizacji sprawców przestępstw na tle seksualnym. Najczęściej stosowane są formy terapii kognitywno-behawioralnej (CBT), które budzą wiele kontrowersji w kontekście osiąganych rezultatów. Nie można jednak zaprzeczyć, że w porównaniu z wieloma różnymi sposobami leczenia stosowanymi wobec tej kategorii sprawców rezultaty terapii CBT są dość obiecujące, choć trudno jednoznacznie określić, czy wszystkie działania stosowane w typowej terapii kognitywno-behawioralnej są niezbędne do osiągniecia pożądanych efektów. Podstawowy „pakiet” oddziaływań stosowany we współczesnych strategiach terapeutycznych, nie wyłączając CBT, obejmuje rozwijanie empatii, restrukturyzację kognitywną, modyfikację dewiacyjnych preferencji i zachowań seksualnych, rozwijanie umiejętności społecznych, kontrolę emocji, kształtowanie umiejętności zapobiegania nawrotom ${ }^{32}$.

Innym przykładem zastosowania terapii kognitywnej jest stosowany w Holandii model terapii TBS, obejmujący leczenie i resocjalizację zaburzonych psychicznie sprawców przestępstw. Stosuje się przede wszystkim modelowanie, bezpośrednią interwencję wobec zachowań pożądanych i niepożądanych

\footnotetext{
29 Tamże, 14.

30 Tamże, 16.

31 Arnold P. Goldstein, Barry Glick, John C. Gibbs, ART. Program zastępowania agresji (Warszawa: Instytut „Amity”, 2004).

32 Tony Ward, Pamela Nathan, Christopher R. Drake, Joseph K.P. Lee, Michele Pathé, „The Role of...”, 252.
} 
(wzmacnianie i wygaszanie) ${ }^{33}$. Połączenie rozwiązań podejścia kognitywnego i behawioralnego stanowi system oddziaływań terapeutycznych wobec sprawców przestępstw na tle seksualnym opracowany przez Rafała Rutkowskiego i Wojciecha Sro$\mathrm{kę}^{34}$. Celem podejmowanych działań jest wykształcenie społecznie akceptowanych sposobów radzenia sobie w sytuacji narastającego niepokoju i pobudzenia seksualnego. Działania te zmierzają do wyposażenia uczestników terapii w umiejętności kontroli własnych zachowań oraz zaspokajania potrzeb w sposób niedestrukcyjny, co może redukować ryzyko powrotu do przestępstwa.

\subsection{Koncepcja integracyjnej teorii zachowania przestępczego jako przykład kierunku wielowymiarowego}

Konsekwencją rozszerzenia pola zainteresowań badawczych, które miały doprowadzić do wskazania bardziej skutecznych interwencji resocjalizacyjnych i korekcyjnych, był kierunek wielowymiarowy nawiązujący do teorii kontroli społecznych. Pojawiająca się w tym nurcie wielość teorii nie pozwoliła na jednoznaczne określenie zarówno teoretycznych przesłanek, jak i rozwiązań metodologicznych, jednak z perspektywy resocjalizacji warto wspomnieć o rozwiązaniach, jakie zaproponowane zostały $\mathrm{w}$ integracyjnej teorii zachowania przestępczego autorstwa Marca LeBlanca. Teoria ta stanowi próbę zintegrowania wzajemnie uzupełniających się czynników społecznych i psychologicznych.

Punktem wyjścia dla rozważań Marca LeBlanca była teoria Travisa Hirschiego, proponująca analizę dewiacji z perspektywy kierunku kontroli społecznej. Zasadniczą tezą tej teorii jest fakt, iż jednostka może dokonywać czynów aspołecznych, ponieważ jej więzi z porządkiem konformistycznym zostały zerwane ${ }^{35}$. Wyjaśnia zatem zachowania ludzi, którzy mimo akceptacji istniejących norm popełniają czyny dewiacyjne (Hirschi wyłączył z obszaru analizy jednostki przejawiające dewiacyjne systemy wartości ze względu na brak konieczności formułowania dodatkowych wyjaśnień) ${ }^{36}$. Dodatkowo model ten, poza opisem uwarunkowań procesu niedostosowania społecznego, wyjaśnia także potencjalne możliwości resocjalizacyjne w kontekście dojrzałości społecznej jednostek niedostosowanych społecznie, kładąc akcent na postępowanie opiekuńcze i doradcze ${ }^{37}$. Odwołując

${ }^{33}$ Zdzisław Majchrzyk, „Resocjalizacja w globalizującym świecie - stare i nowe wyzwania”. W: Współczesne oblicze resocjalizacji penitencjarnej, red. Sylwester Bębas (Radom: Wyższa Szkoła Handlowa, 2010), 251.

${ }^{34}$ Rafał Rutkowski, Wojciech Sroka, „Projekt systemu oddziaływań terapeutycznych wobec sprawców przestępstw na tle seksualnym w okresie odbywania kary pozbawienia wolności". Seksuologia Polska 5 (2007), 1-8.

${ }^{35}$ Andrzej Siemaszko, Granice tolerancji. Wokół teorii zachowań dewiacyjnych (Warszawa: Wydawnictwo Naukowe PWN, 1993), 235-236.

${ }^{36}$ Małgorzata H. Kowalczyk, Zabójcy i mordercy. Czynniki ryzyka i możliwości oddziaływań resocjalizacyjnych (Kraków: Oficyna Wydawnicza „Impuls”, 2010), 25.

${ }^{37}$ Konopczyński, „Współczesne nurty..., 206. 
się do teorii Hirschiego, LeBlanc przyjął, że każdy człowiek może podejmować zachowania przestępcze $\mathrm{w}$ sytuacjach zerwania lub osłabienia więzi społecznych w zakresie przywiązania, zobowiązania, zaangażowania czy przekonania.

Wszystkie korelacje przeanalizowane w ramach więzi społecznych pozwoliły na ukazanie dwóch znaczących faktów: $\mathrm{z}$ jednej strony przywiązanie do osób traktować należy jako pierwotne względem zaangażowania wobec instytucji społecznych, a zachowania przestępcze wynikają w tym przypadku z pierwszej korelacji, ale za pośrednictwem drugiej. Natomiast słabe więzi ze społeczeństwem stanowią, na poziomie pośrednim, źródło postaw nonkonformistycznych oraz przyczynę dysfunkcji szkolnych. Ten pośredni skutek słabości więzi działa jak mechanizm popychający w kierunku zachowań przestępczych.

Zdaniem Marca LeBlanca zachowania przestępcze wynikają jednocześnie ze słabych więzi społecznych oraz z niedojrzałości psychicznej, a wpływ tych czynników potęgują powściągi zewnętrzne i wewnętrzne. Zdaniem Lesława Pytki przestępstwo lub wstrzymanie się od jego popełnienia jest zależne od przebiegu socjalizacji jednostki, który to proces jest uzależniony od stopnia kontroli oraz siły powściągów i ograniczeń wywieranych na jednostkę ${ }^{38}$. Zatem ryzyko antyspołecznego zachowania jest wyższe $\mathrm{u}$ jednostek narażonych na oddziaływanie słabych więzi społecznych oraz będących osobami wyraźnie opóźnionymi w rozwoju psychicznym. Sposób adaptacji, charakteryzujący się antagonizmem destruktywnym, skutkuje wysoką inklinacją ku zachowaniom przestępczym. Natomiast za czynniki hamujące zachowania przestępcze należy uznać siłę więzi społecznych, odpowiedni rozwój psychiczny, przymus społeczny, zgodność ze społeczną rolą. Przymus społeczny stanowi bowiem barierę chroniącą przed naciskami popychającymi do zachowań przestępczych, które mogą wynikać ze słabości więzów społecznych lub z opóźnienia rozwoju osobowości.

Słabe przywiązanie do osób i słabe zaangażowanie względem instytucji w połączeniu z opóźnionym rozwojem psychicznym mogą prowadzić do zachowań przestępczych i/lub do marginalizacji, która wiąże się m.in. z poszukiwaniem znajomych wśród przestępców, co także popycha jednostkę w kierunku zachowań aspołecznych. Solidne więzi ze społeczeństwem w połączeniu z normalnym rozwojem psychicznym otwierają na działanie przymusu społecznego i chronią przed podejmowaniem zachowań przestępczych, gdyż jednostka właściwie pełni swoją funkcję społeczną ${ }^{39}$.

Założenia integracyjnej teorii regulacji zachowań odbiegających od normy jako pierwszy zweryfikował $\mathrm{w}$ badaniach empirycznych sam autor. Uzyskane wyniki pozwalają stwierdzić, iż więzi między rodzicami a dziećmi są pierwotną

38 Lesław Pytka, Pedagogika resocjalizacyjna (Warszawa: Wydawnictwo Akademii Pedagogiki Specjalnej, 2000), 57-58.

39 Por. m.in. Kowalczyk, Zabójcy i mordercy..., 25-28 oraz Lesław Pytka, Tamara Zacharuk, Zaburzenia przystosowania społecznego dzieci i młodzieży. Aspekty diagnostyczne i terapeutyczne (Siedlce: Wyższa Szkoła Rolniczo-Pedagogiczna, 1998). 
formą przywiązania, która rzutuje na inne związki. Czynnikiem najbardziej kryminogennym jest styczność z przestępczymi przyjaciółmi. W dalszej kolejności brak autorytetów, zaburzona komunikacja w rodzinie oraz brak przywiązania do rodziców jako osób socjalizująco znaczących ${ }^{40}$. Badania potwierdziły hipotezy, jakie sformułował LeBlanc, wskazując, że słabość mechanizmów regulacji zachowania wyraża się $\mathrm{w}$ ograniczonych więziach ze społeczeństwem wywierającym konformizujący wpływ na zachowanie, w ograniczonym rozwoju psychicznym jednostki oraz w deficytach powściągów społecznych, czyli kontroli zewnętrznej i wewnętrznej ${ }^{41}$.

Marcel Frechette oraz Marco LeBlanc, na podstawie analiz psychologiczno-kryminologicznych, wyodrębnili trzy strefy kształtowania się odmian zachowania dewiacyjnego ${ }^{42}$ :

I. strefa przestępczości, a w niej takie podtypy dewiacyjne, jak przestępca aspołeczny i socjopatyczny; jeśli na podstawie rozpoznania diagnostycznego, uwzględniającego stan mechanizmów kontroli wewnętrznej i zewnętrznej, znajdzie się w tej strefie nieletni, wówczas konieczne są działania kliniczno-lecznicze (leczenie zaburzeń osobowości), interwencyjne (sądowe, policyjne, powstrzymujące od zachowań przestępczych i chroniące społeczeństwo) oraz typowo izolacyjne, a następnie resocjalizacyjne;

II. strefa marginalizacji, a w niej przestępca o strukturze neurotycznej, marginalny, o osobowości nieadekwatnej itd.; jeśli w tej strefie mieści się nieletni, można podejrzewać, że istnieją u niego deficyty rozwojowe i zaburzenia osobowości, a wówczas zasadne jest skierowanie do właściwej placówki konsultacyjnej lub/i terapeutycznej;

III. strefa zsocjalizowania - w jej obrębie wyróżnia się nieletniego normalnie rozwiniętego, który popełnia wykroczenia i drobne przestępstwa, oraz nieletniego bez zaburzeń psychologicznych, który popełnia przestępstwa, ale jego aktywność przestępcza jest stosunkowo niska; jeśli nieletni mieści się w sferze zsocjalizowania, wówczas zasadne są działania prewencyjne obejmujące szkołę, dom, rówieśników i przyjaciół ${ }^{43}$.

LeBlanc wykazał, że wszelkie postępy w resocjalizacji są związane z podejmowaniem zindywidualizowanych i zróżnicowanych oddziaływań. Nie sposób pominąć praktycznych implikacji w zakresie konstruowania obrazu diagnostycznego przypadku uwzględniającego zindywidualizowane czynniki etiologiczne, otwierające tym samym drogę do tworzenia indywidualnych strategii oddziaływań resocjalizacyjnych czy korekcyjnych. Właściwie zorganizowany proces resocjalizacji wiąże się ze zróżnicowanymi i zindywidualizowanymi oddziaływaniami

\footnotetext{
40 Pytka, Pedagogika..., 60-61.

${ }^{41}$ Tamże, 63.

42 Tamże, 64-65.

43 Tamże.
} 
korekcyjnymi, nie można bowiem w tożsamy sposób reagować na rozmaite typy dewiacyjne ${ }^{44}$. Zdaniem LeBlanca jeśli mechanizmy socjalizacyjne w sposób właściwy kontrolują poszanowanie innych osób oraz powściągają i ograniczają impulsy popędowo-emocjonalne, to mamy do czynienia z socjalizacją prawidłową i nie występują $\mathrm{w}$ konsekwencji zachowania przestępcze. W pozostałych przypadkach podejście integracyjne daje szereg możliwości zaplanowania i zrealizowania działań zarówno natury profilaktycznej, jak i resocjalizacyjnej o różnym stopniu zaawansowania. Wobec jednostki sytuującej się w strefie „marginalizacji” należy kompensować występujące deficyty rozwojowe, podejmując oddziaływania terapeutyczne. Jeśli wykazuje cechy wadliwego zsocjalizowania, to działania powinny mieć charakter profilaktyczny. W przypadku, gdy jednostka lokalizuje się w strefie przestępczości, najbardziej adekwatne działania mają charakter resocjalizacyjny sytuowany instytucjonalnie ${ }^{45}$.

\subsection{Model dobrego życia jako przykład oddziaływań skoncentrowanych na potencjałach jednostki}

Współczesna myśl resocjalizacyjna coraz częściej odwołuje się do kierunków oddziaływań, w których centralną ideą staje się odwołanie do potencjałów jednostki, możliwości rozwijania jej zasobów, a nie wyłącznie redukowania deficytów, często stających się źródłem zaburzonych zachowań, nierzadko inicjujących i ukierunkowujących przebieg kariery przestępczej. Przemyślana działalność resocjalizacyjna, jak pisze Bronisław Urban, powinna opierać się zarówno na rejestrowaniu i analizie niekorzystnych czynników oddziałujących na jednostkę, jak i stymulowaniu wpływu innych czynników mogących te negatywne czynniki równoważyć ${ }^{46}$. Źródłem inspiracji może być koncepcja resilience (oporu - elastyczności). Płaszczyzną oporu, umożliwiającą odwrócenie niekorzystnego przebiegu socjalizacji, mogą być odkryte i uaktywnione potencjały jednostki, zarówno zalążki talentów, jak i predyspozycji osobowościowych ${ }^{47}$. Najbardziej znanym przykładem odwołującym się do wykorzystania potencjałów jednostki w planowaniu pracy resocjalizacyjnej jest twórcza resocjalizacja według koncepcji Marka Konopczyńskiego.

Model GLM jest jednym z modeli koncentrujących się na mocnych stronach jednostki, a nie na podkreślaniu psychospołecznych deficytów. Został opracowany jako alternatywne rozwiązanie teoretyczne, które zachowując zalety tradycyjnych podejść wobec interwencji resocjalizacyjnej, jednocześnie podkreśla aktywne zaangażowanie uczestników procesu resocjalizacji w kształtowaniu zachowań

44 Tamże, 65.

45 Konopczyński, „Współczesne nurty..., 207.

46 Por. Bronisław Urban, Zachowania dewiacyjne młodzieży w interakcjach rówieśniczych (Kraków: Wydawnictwo Uniwersytetu Jagiellońskiego, 2005).

47 Konopczyński, Metody..., 39. 
prospołecznych i zaniechaniu aktywności przestępczej ${ }^{48}$. Zasadniczym celem podejmowanych interwencji jest wyposażenie podopiecznych w zasoby zarówno wewnętrzne, jak i zewnętrzne, które pozwolą na kształtowanie idei „dobrego życia" w zgodzie z oczekiwaniami tak społecznymi, jak i osobistymi. Jednym z głównych założeń modelu jest przekonanie, że człowiek z natury jest skłonny do poszukiwania określonych rodzajów doświadczeń i dóbr oraz że odczuwa wysoki poziom dobrego samopoczucia, jeżeli te dobra znajdzie. Zgodnie z tym modelem zachowania przestępcze powstają, gdy jednostka nie ma wewnętrznych lub zewnętrznych zasobów do osiągania swoich celów w prospołeczny sposób. Zakłada się, że problemy przestępcze i psychologiczne są bezpośrednią konsekwencją złych prób osiągania znaczących dla jednostki dóbr ${ }^{49}$.

Porzucenie zachowań przestępczych jest zatem możliwe, gdy wyposaży się te jednostki w wiedzę, umiejętności, zasoby i szansę do prowadzenia „dobrego życia”, które będą uwzględniały ich preferencje, zainteresowania i wartości.

Zasadniczym celem resocjalizacji jest umożliwienie osobie stworzenia planu życia obejmującego sposoby skutecznego zdobywania podstawowych dóbr bez krzywdzenia innych. Nie chodzi tu tylko o zmniejszanie czynników ryzyka, ale całościową rekonstrukcję tożsamości jednostki. Podejście to wymaga poznania „mocnych stron” jednostki, podstawowych dóbr, właściwości środowiska, w którym funkcjonuje, oraz uwzględnienia możliwości jednostki w kwestii decydowania o sobie.

Tony Ward i Shadd Maruna zaproponowali jedenaście klas dóbr podstawowych obejmujących: (1) życie (w tym zdrowe życie i funkcjonowanie); (2) wiedzę; (3) doskonałość w aktywności (zabawie, grze, rozrywce [play]); (4) doskonałość w pracy (w tym doświadczenie mistrzowskie); (5) doskonałość w działaniu ( $\mathrm{tj}$. autonomia i samokształcenie); (6) spokój wewnętrzny ( $\mathrm{tj}$. uwolnienie od emocjonalnego zamętu i stresu); (7) przyjaźń (w tym związki intymne, romantyczne i rodzinne); (8) społeczność; (9) duchowość (w szerokim sensie odnajdywania sensu i celu życia); (10) szczęście; (11) kreatywność ${ }^{0}$. Można założyć, że wszyscy ludzie dążą do tych samych dóbr, jednak należy mieć na uwadze indywidualne priorytety życiowe hierarchizujące wspomniane dobra. W związku z tym interwencje resocjalizacyjne ukierunkowane na powstrzymanie procesu recydywy winny koncentrować się na wskazywaniu prospołecznych sposobów osiągnięcia podstawowych dóbr ważnych z punku widzenia podopiecznego. Zablokowanie dostępu do dóbr podstawowych bez wskazywania alternatywnych sposobów ich

${ }_{48}$ Gwenda Willis, Tony Ward, „The Good Lives Model: Evidence that it Works”. W: What Works in Offender Rehabilitation: An Evidence Based Approach to Assessment and Treatment, eds. Leam A. Craig, Louise Dixon, Theresa A. Gannon (West Sussex, UK: John Wiley \& Sons, 2013), 306.

49 Tamże, 308

50 Za: tamże. 
osiągnięcia może doprowadzić do frustracji, braku umiejętności formułowania celów, a ostatecznie zwiększyć ryzyko powrotu do zachowań przestępczych ${ }^{51}$.

Koncepcja GLM zakłada, że ludzie koncentrują się w życiu na realizacji podstawowych wartości, budując wokół nich swój plan życiowy. Zachowania przestępcze są wynikiem błędów w tworzeniu planu życiowego oraz podejmowania bezpośrednich, jak i pośrednich działań zmierzających do realizacji podstawowych dóbr. Działania bezpośrednie oznaczają, że jednostka dąży do zdobycia nieosiągalnych dla niej dóbr, podejmując działania przestępcze. Zasadniczą cechą działań bezpośrednich jest świadome stosowanie nieaprobowanych środków.

Natomiast działania pośrednie mają miejsce wówczas, gdy dana osoba nie ma bezpośredniego zamiaru łamania prawa, jednak nie potrafi w sposób społecznie aprobowany zdobywać istotnych dla niej dóbr ${ }^{52}$.

Działania resocjalizacyjne formułowane są wspólnie z podopiecznym i przekładane na plan interwencji Good Lives (GL). Interwencje mają na celu uzupełnienie repertuaru sprawności klienta poprzez wzmocnienie jego zdolności do osiągania wartościowanych dóbr w społecznie akceptowany sposób. Koncepcja GLM opiera się na zastosowaniu siedmiu modułów ujmowanych w programach leczenia i terapii różnych kategorii przestępców z uwzględnieniem między innymi przestępców seksualnych.

Moduły te obejmują:

- ustalenie norm terapii,

- restrukturyzację poznawczą,

- radzenie sobie z dewiacyjnym pobudzeniem,

- wpływ na ofiarę i trening empatii,

- regulację wpływu,

- trening umiejętności społecznych i zapobieganie nawrotom ${ }^{53}$.

Autorzy podkreślają, że większość modułów kojarzy się z nadrzędnymi dobrami podstawowymi, którymi może być na przykład, w zrozumieniu modułu kognitywnej restrukturyzacji, wiedza, osiągnięta poprzez dostarczenie przestępcom informacji, w jaki sposób ich myśli, uczucia i działania doprowadziły ich do złamania prawa. Natomiast moduł szkolenia umiejętności społecznych jest związany z nadrzędnymi dobrami, takimi jak przyjaźń czy prospołeczność. Nadrzędne dobra, realizowane za pośrednictwem każdego modułu, powinny zostać wyraźnie powiązane z planami „dobrego życia” (GL) poszczególnych klientów indywidualnych ${ }^{54}$. Indywidualny plan GL każdego członka grupy (w warunkach instytucjonalnych) powinien informować o charakterze planowanych wobec niego interwencji, co oznacza, że niektóre formy oddziaływań - a niewykluczone,

\footnotetext{
Tamże.

52 Tamże.

33 Tamże, 308 i dalej.

54 Tamże.
} 
że i całe moduły - mogą być nieodpowiednie dla niektórych kategorii sprawców. Dopasowywanie treści interwencyjnej i intensywności oddziaływań do indywidualnych planów GL klienta jest najbardziej skuteczne w przypadku terapii grupowej, realizowanej w postaci tak zwanych grup ciągłych zamiast grup zamkniętych (oznacza to, że nowy uczestnik dołącza do grupy w momencie, gdy inny zostaje zwolniony, co powoduje, że członkowie grupy znajdują się na różnych etapach terapii i postępów resocjalizacyjnych). Jednym z elementów indywidualnego planu GL jest także podejmowanie interwencji w celu rozwijania umiejętności tworzenia prospołecznych relacji.

Model GLM nawiązuje do modelu R-N-R, czyli modelu ryzyka - potrzeby reaktywności, który jest przykładem podejścia związanego z szacowaniem ryzyka. W związku z tym zastosowanie modelu GL oznacza, że wraz z zasadą potrzeby uwzględnia się również zasady R-N-R dotyczące ryzyka i reaktywności. Zasada ryzyka ma znaczenie $z$ uwagi na to, że osoby charakteryzujące się wysokim poziomem ryzyka powrotności zazwyczaj doświadczają większych problemów z wewnętrzną i zewnętrzną zdolnością do osiągnięcia prospołecznych celów osobistych niż osoby o niskim poziomie ryzyka, a zatem wymagają większej intensywności interwencji terapeutycznej. Zgodnie z zasadą ryzyka osoby sytuujące się w kategorii niskiego ryzyka zazwyczaj wymagają minimalnej interwencji terapeutycznej, zatem mogą czerpać większe korzyści dzięki praktycznemu wsparciu w warunkach wolnościowych, pozwalających na skuteczne wdrożenie planów GL.

Reasumując, GLM stanowi koncepcję resocjalizacyjną, której zadaniem jest wskazanie zakresu celów i wartości leżących u podstaw interwencji resocjalizacyjnych, nie jest natomiast propozycją konkretnego modelu leczenia. Jej celem jest zapewnienie kompleksowych rozwiązań dla praktyki resocjalizacyjnej. $\mathrm{W}$ istocie funkcjonuje ona jako szeroko pojmowana matryca, którą należy uzupełnić konkretnymi działaniami bazującymi na określonych teoriach (na przykład poznawczo-behawioralnych), adekwatnych do zamierzonych interwencji ${ }^{55}$.

\section{Podsumowanie}

Omówione wybrane kierunki oddziaływań resocjalizacyjnych wskazują na ich różnorodność oraz możliwość łączenia pewnych idei w celu uzyskania jak najlepszych rezultatów podejmowanych interwencji. Realizowane oddziaływania resocjalizacyjne nie zawsze jednak przynoszą oczekiwany skutek w postaci długotrwałego odstąpienia od zachowań przestępczych. Analiza zróżnicowanych koncepcji teoretycznych, opartych na rozwiązaniach behawioralnych, kognitywno-behawioralnych, wielowymiarowych i nawiązujących do ruchu

55 Tamże, 312. 
evidence-based practice, umożliwiła wskazanie różnego zakresu zastosowania oddziaływań korekcyjnych. Przewodnią ideą omówionych nurtów jest eksponowanie przewagi metod doradczych i terapeutycznych $\mathrm{w}$ postępowaniu resocjalizacyjnym nad metodami represyjnymi.

Streszczen ie: Poszukiwanie skutecznych sposobów oddziaływań resocjalizacyjnych opiera się na zróżnicowanych nurtach teoretycznych, które jednak nie mogą być utożsamiane z teoriami kryminologicznymi. Modele oddziaływań resocjalizacyjnych nawiązują do wielu nurtów teoretycznych różniących się metodologicznie i prakseologicznie. Wśród najważniejszych nurtów wymienia się koncepcje behawioralne, psychodynamiczne, kognitywno-behawioralne, interdyscyplinarne czy interakcyjne. Na uwagę zasługują także modele oddziaływań korekcyjnych nawiązujących do ruchu evidence based practice, którego przykładami mogą być modele R-N-R i Good Life Model. Celem niniejszego opracowania jest scharakteryzowanie wybranych, podstawowych modeli oddziaływań korekcyjnych stosowanych obecnie w procesie resocjalizacji osób z zaburzeniami w zachowaniu, niedostosowanych społecznie i sprawców przestępstw. Z uwagi na teoretyczny charakter opracowania wykorzystano metodę przeszukiwania źródeł wtórnych.

Słowa kluczowe: niedostosowanie społeczne, zaburzenia w zachowaniu, kierunek behawioralny, model kognitywny, kierunek wielowymiarowy, model dobrego życia

\section{Bibliografia}

Goldstein, Arnold P., Glick, Barry, Gibbs, John C. ART. Program zastępowania agresji. Warszawa: Instytut „Amity”, 2004.

Konopczyński, Marek. Metody twórczej resocjalizacji. Warszawa: Wydawnictwo Naukowe PWN, 2006.

Konopczyński, Marek. „Współczesne nurty w resocjalizacji”. W: Resocjalizacja, red. Bronisław Urban, Jan Maria Stanik. Warszawa: Wydawnictwo Naukowe PWN, 2007, 203-210.

Kowalczyk, Małgorzata H. Zabójcy i mordercy. Czynniki ryzyka i możliwości oddziaływań resocjalizacyjnych. Kraków: Oficyna Wydawnicza „Impuls”, 2010.

Majchrzyk, Zdzisław. „Resocjalizacja w globalizującym świecie - stare i nowe wyzwania”. W: Współczesne oblicze resocjalizacji penitencjarnej, red. Sylwester Bębas. Radom: Wyższa Szkoła Handlowa, 2010, 239-256.

Muskała, Maciej. Odstąpienie od przestępczości w teorii i praktyce resocjalizacyjnej. Poznań: Wydawnictwo Naukowe UAM, 2016.

Pospiszyl, Kazimierz. Resocjalizacja. Warszawa: Wydawnictwo Akademickie „Żak”, 1998.

Pytka, Lesław. Pedagogika resocjalizacyjna. Warszawa: Wydawnictwo Akademii Pedagogiki Specjalnej, 2000.

Pytka, Lesław, Zacharuk, Tamara. Zaburzenia przystosowania społecznego dzieci i młodzieży. Aspekty diagnostyczne i terapeutyczne. Siedlce: Wyższa Szkoła Rolniczo-Pedagogiczna, 1998.

Rubacha, Krzysztof. Metodologia badań nad edukacja. Warszawa: Wydawnictwo Akademickie i Profesjonalne, 2008. 
Rutkowski, Rafał, Sroka, Wojciech. „Projekt systemu oddziaływań terapeutycznych wobec sprawców przestępstw na tle seksualnym w okresie odbywania kary pozbawienia wolności”. Seksuologia Polska 5 (2007), 1-8.

Siemaszko, Andrzej. Granice tolerancji. Wokół teorii zachowań dewiacyjnych. Warszawa: Wydawnictwo Naukowe PWN, 1993.

Stanik, Jan Maria. „Diagnozowanie niedostosowania społecznego i asocjalności”. W: Resocjalizacja, red. Bronisław Urban, Jan Maria Stanik. Warszawa: Wydawnictwo Naukowe PWN, 2007, $168-202$.

Urban, Bronisław. „Współczesne teorie w naukach społecznych wobec przestępczości i resocjalizacji”. W: Działalność resocjalizacyjna i profilaktyczna, w środowisku otwartym, instytucjach wychowawczych, poprawczych oraz karnych, red. Teresa Sołtysiak, Agnieszka Latoś. Bydgoszcz: Wydawnictwo UKW, 2010, 11-19.

Urban, Bronisław. „Zaburzenia w zachowaniu i niedostosowanie społeczne w świetle współczesnych wyników badań". W: Resocjalizacja, red. Bronisław Urban, Jan Maria Stanik. Warszawa: Wydawnictwo Naukowe PWN, 2007, 136-167.

Urban, Bronisław. Zaburzenia w zachowaniu i przestępczość młodzieży. Kraków: Wydawnictwo Uniwersytetu Jagiellońskiego, 2000.

Urban, Bronisław. Zachowania dewiacyjne młodzieży w interakcjach rówieśniczych. Kraków: Wydawnictwo Uniwersytetu Jagiellońskiego, 2005.

Ward, Tony, Nathan, Pamela, Drake, Christopher R., Lee, Joseph K.P., Pathé, Michele. „The Role of Formulation-based Treatment for Sexual Offenders". Behaviour Change 4 (2000), 251-264.

Willis, Gwenda, Ward, Tony. „The Good Lives Model: Evidence that it Works”. W: What Works in Offender Rehabilitation: An Evidence Based Approach to Assessment and Treatment, eds. Leam A. Craig, Louise Dixon, Theresa A. Gannon. West Sussex, UK: John Wiley \& Sons, 2013, 305-318. 